\title{
At Least Two Mechanisms Are Involved in the Death of Retinal Ganglion Cells Following Target Ablation in Neonatal Rats
}

\author{
Q. Cui and A. R. Harvey \\ Department of Anatomy and Human Biology, The University of Western Australia, Nedlands, Perth, \\ WA 6907, Australia
}

Removal of the superior colliculus (SC) in neonatal Wistar rats results in a rapid loss of retinal ganglion cells (RGCs). There is an early twofold increase in RGC death 4-8 hr postlesion ( $P L)$ followed by a later 10-11-fold increase in pyknosis about $24 \mathrm{hr}$ PL. We have now used neurotrophic factors (BDNF, NT-4/5, NT-3, NGF, LIF), glutamate receptor antagonists (MK-801, DNQX, CNQX), an antioxidant ( $\mathrm{N}$-acetyl-L-cysteine), and an NOS inhibitor (L-NAME) to determine whether the early and late phases of lesion-induced RGC death involve similar or different mechanisms. Normal and pyknotic nuclei of tectally projecting RGCs were visualized by injecting the left SC of $\mathbf{2}$ d old rats with diamidino yellow (DY). Two days later the injection site was removed. In most rats, right eyes were injected with factors immediately after the SC ablation. Rats were perfused either 6 or 24 hr PL. In the latter group a second intravitreal injection of the appropriate factor was sometimes made 12 hr PL. NT4/5 and BDNF significantly decreased RGC pyknosis 6 and $24 \mathrm{hr}$ PL, whereas NT-3 was only protective $6 \mathrm{hr}$ PL. LIF slightly reduced RGC death $24 \mathrm{hr}$ PL, but NGF had no influence on RGC survival at either time point. NT-4/5 also reduced the rate of naturally occurring $R G C$ death. MK-801, DNQX, CNQX, $\mathrm{N}$-acetylcysteine, and L-NAME all prevented the early lesion-induced increase in RGC death but had no significant effect on RGC death measured 24 hr PL; none of these factors significantly reduced the rate of naturally occurring RGC death. Cycloheximide, shown previously to reduce $\mathrm{RGC}$ pyknosis $24 \mathrm{hr}$ PL, did not prevent RGC death $6 \mathrm{hr}$ PL. The data indicate that there are at least two mechanisms involved in RGC death after neonatal target ablation. The early increase is related to excitotoxic effects mediated by glutamate receptors and involves NOS and the production of free radicals. We found no evidence that RGC death measured $24 \mathrm{hr} \mathrm{PL}$ is dependent on these processes, but the later death does require protein synthesis and, most likely, the activation of an endogenous suicide program. NT-4/5 and BDNF protected RGCs from both types of lesion-induced death.

[Key words: retinal ganglion cells, NT-4/5, brain-derived

Received Mar. 14, 1995; revised Aug. 7, 1995; accepted Aug. 16, 1995.

We are indebted to Genentech for the gift of BDNF, NT-3, and NT-4/5, and to Merck, Sharp and Dohme for the gift of MK-801. We also thank Bob Rush for supplying NGF and Perry Bartlett for supplying LIF. We thank Bob Rush and Alun Davies for comments on the manuscript. Supported by a grant from the Australian NHMRC. C.Q. is supported by an overseas postgraduate research scholarship from The University of Western Australia.

Correspondence should be addressed to Alan Harvey at the above address. Copyright 1995 Society for Neuroscience $0270-6474 / 95 / 158143-13 \$ 05.00 / 0$ neurotrophic factor (BDNF), NT-3, NGF, leukemla Inh/bitory factor (LIF), glutamate receptor antagonists, excitotoxicity, nitric oxide synthase, free radicals, apoptosis]

A major goal of neuroscience research is to elucidate the mechanisms underlying cell death in the CNS and PNS. Much of this work is directed toward identifying the factors that regulate cell survival during normal CNS and PNS development (reviewed in Oppenheim, 1991; Johnson and Deckworth, 1993; Davies, 1994). Other research is aimed at finding ways of promoting cell viability after acute traumatic insults or in chronic neurodegenerative disease in the adult nervous system (for recent reviews, see Mattson et al., 1993; Hefti, 1994; Lindsay et al., 1994: Lindvall et al., 1994; Mattson and Scheff, 1994). These studies are complementary; understanding the cause of neuronal death in one situation may shed light on the processes involved in neuronal death in other conditions.

In many parts of the developing mammalian visual system, as in other systems in the CNS, there is a wave of naturally occurring (or programmed) neuronal death (Finlay and Pallas, 1989). In the rat retina there is an initial overproduction of retinal ganglion cells (RGCs) followed by elimination of about $50 \%$ of the population. Loss of RGCs occurs just before birth and in the first few postnatal days (Dreher et al., 1983; Perry et al., 1983). It is generally accepted that developing neurons compete with each other for limited amounts of target-derived neurotrophic factors; experimental enlargement of targets reduces cell death whereas axonal damage or target ablation has the opposite effect (Oppenheim, 1991; Snider et al., 1992; Sohal, 1992). Consistent with this, fewer RGCs survive into adulthood after axotomy or removal of central target sites in neonatal rats (Perry and Cowey, 1979; Carpenter et al., 1986; Horsburgh and Sefton, 1987).

Recently we described the time course and extent of death of identified retinotectally projecting ganglion cells following neonatal ablation of the rat superior colliculus (SC; Harvey and Robertson, 1992). Removal of this central target at P4 (day of birth $=\mathrm{P}($ ) resulted in the rapid loss of about $50 \%$ of the normal RGC population. There was an early increase in the number of dying (pyknotic) RGCs 4-8 hr postlesion (PL); the rate at this time was about $2 \%$, twice the naturally occurring RGC death rate. This early increase in cell death was followed by a much larger increase in death that peaked at about $24 \mathrm{hr}$ PL (Harvey and Robertson, 1992). The proportion of pyknotic to normal RGCs was $8-11.5 \%$ at this time (Harvey and Robertson, 1992; Harvey et al., 1994). Harvey and Robertson (1992) proposed that the early increase in RGC death might be caused by different mechanisms to those involved in the later wave of cell death. 
Further studies revealed that intravitreal injection of cycloheximide (CHX), but not ganglioside GM1, substantially reduced RGC pyknosis $24 \mathrm{hr}$ PL (Harvey et al., 1994). These data were consistent with the proposal that RGC death 16-50 hr after target ablation was an active process requiring protein synthesis and, possibly, activation of some form of endogenous suicide program within the neurons (Martin et al., 1988; Oppenheim et al., 1990; Scott and Davies, 1990; Johnson and Deckworth, 1993). Recent studies in the rat retina by Rabacchi et al. (1994) are consistent with this view. However, the cause of the rapid increase in $\mathrm{RGC}$ death in the first few hours after SC removal remained undetermined.

Exogenous application of neurotrophins and other growth factors can protect a diverse range of neuronal types in both the developing and mature CNS and PNS (Johnson and Deckworth, 1993; Mattson et al., 1993; Davies, 1994; Hefti, 1994; Lindsay et al., 1994; Lindvall et al., 1994; Mattson and Scheff, 1994). In studies in the visual system, we recently showed that intravitreal injection of the neurotrophin NT-4/5 significantly reduced naturally occurring RGC death in neonatal rats (Cui and Harvey, 1994b). Others have reported that survival of adult RGCs after axotomy or ischemia can be promoted by a variety of trophic factors, applied either intraocularly or to the cut end of the optic nerve. These factors include brain-derived neurotrophic factor (BDNF; Mey and Thanos, 1993; Mansour-Robaey et al., 1994; Unoki and LaVail, 1994), NT-4/5 (Cohen et al., 1994), nerve growth factor (NGF; Carmignoto et al., 1989; Siliprandi et al., 1993), ciliary neurotrophic factor (CNTF; Mey and Thanos, 1993; Unoki and LaVail, 1994), and acidic and basic fibroblast growth factors (aFGF and bFGF; Sievers et al., 1987; Unoki and LaVail, 1994). It is not known whether these (or other) neurotrophic factors have a protective effect on developing RGCs isolated in vivo from their central targets. We therefore carried out SC ablation experiments in neonatal rats (Harvey and Robertson, 1992; Harvey et al., 1994) and then injected a variety of neurotrophic factors into the eyes to determine if they enhanced RGC survival after target removal. Factors that were used were NT-4/5, BDNF, NGF, neurotrophin NT-3, and leukemia inhibitory factor (LIF). The main objective of this study was to determine the relative effects of these neurotrophic factors at different times after SC ablation. To this end, the extent of RGC death in the presence of neurotrophins was analyzed at $6 \mathrm{hr}$ as well as $24 \mathrm{hr}$ PL (i.e., during the early and late phases of lesioninduced death).

In order to test whether any of the RGC death observed after neonatal tectal lesions could be attributed to excessive stimulation of glutamate receptors and subsequent excitotoxic effects (Facci et al., 1990; Abu El Asrar et al., 1992; Choi, 1992; Siliprandi et al., 1992; Akaike et al., 1994), eyes of some rats were injected with dizocilpine maleate (MK-801), a noncompetitive antagonist of $N$-methyl-D-aspartate (NMDA)-type glutamate receptors (Wong et al., 1986). Eyes in other rats were injected with either 6,7-dinitroquinoxaline-2,3-dione (DNQX) or 6-cyano-7-nitroquinoxaline-2,3-dione (CNQX), competitive inhibitors of non-NMDA glutamate channels (Honorè et al., 1988). As in the neurotrophic factor studies, the impact of these drugs on RGC death was assessed 6 and 24 hr PL.

There is evidence that glutamate neurotoxicity is, at least in part, mediated by nitric oxide (NO) and free radicals (Dawson et al., 1991; Lipton et al., 1993; Brorson et al., 1994; Mayer and Noble, 1994; Dawson and Dawson, 1995). In some systems it has also been shown that antioxidants prevent or delay apoptosis
(Ferrari et al., 1995; Greenlund et al., 1995). We therefore examined whether RGC survival 6 or 24 hr PL was enhanced after intraocular injection of either $\mathrm{N}^{\omega}$-nitro-L-arginine methyl ester (L-NAME), an inhibitor of nitric oxide synthase (NOS; Moncada et al., 1991), or $N$-acetyl-L-cysteine (NAC), an antioxidant that scavenges free radicals and also raises intracellular glutathione levels (Meister, 1988; Mayer and Noble, 1994; Ferrari et al., 1995).

Finally, we showed previously that blockade of protein synthesis enhanced RGC survival 24 hr PL (Harvey et al., 1994; cf. Rabacchi et al., 1994). To help determine whether the intracellular mechanisms regulating cell survival during the early and late phases of RGC death were the same or different, we repeated the intraocular $\mathrm{CHX}$ injections after SC ablation, but assessed their effectiveness 6 hr PL.

Preliminary accounts of some of these data have been presented in abstract form (Cui and Harvey, 1994a, 1995).

\section{Materials and Methods}

The method used has been published in detail elsewhere (Harvey and Robertson, 1992; Harvey et al., 1994). Briefly, RGCs in the right eye were retrogradely labeled by injection of the nucleophilic fluorescent dye diamidino yellow (DY) into the middle of the left SC of etheranesthetized Wistar rats at P2. Care was taken to ensure that the injections were as superficial as possible. Animals were not used if there was excessive bleeding or if the DY injection was too large and/or caused ohservable damage to the SC. With slow, small injections (ahout $0.1 \mu \mathrm{l})$ this method consistently and effectively labels tectally projecting RGCs in the topographically related part of contralateral retina. In retinas of nonlesioned P4/P5 rats the mean density of normal DY labeled RGCs ranged from 5500 to $6300 \mathrm{~mm}^{2}$ (Harvey and Robertson, 1992; Cui and Harvey, 1994b), a figure close to that seen in similarly aged retirlas using oller techniques (McCall el al., 1987). At P4, 2 d after the DY injections, rats were again anesthetized with ether and the area of the left SC containing the DY injection site was removed by gentle aspiration.

Intraocular injections. Drugs and trophic factors were injected into the right eye of ether-anesthetized rats through a glass pipette inserted into the vitreous chamber. The injections were made in the most peripheral part of lower temporal retina, as close as possible to the ora serrata (cornea-sclera junction). The volume of each injection was 1.0 $\mu l$. In almost all cases the first eye injection was made immediately after $\mathrm{SC}$ removal $(0 \mathrm{hr})$. For rats surviving $24 \mathrm{hr} \mathrm{PL}$ a second injection was sometimes made $12 \mathrm{hr}$ later (see Table 2). In some NT-4/5-treated animals the second intravitreal injection was made 5, 8, or $20 \mathrm{hr}$ PL, while in other NT-4/5 experiments the first injection was not made until 12, 16, or $20 \mathrm{hr}$ after the lesion (see Table 3). Most animals were perfused either 6 or $24 \mathrm{hr}$ after SC ablation. The exception was the NT4/5-treated group, in which a number of animals were perfused 16, 32, 38 , or 48 hr PL.

MK-801 (Merck, Sharp and Dohme), DNQX (Tocris Cookson), and CNQX (Sigma) were all used at $100 \mathrm{~nm}$ concentrations. NAC (Sigma) was used at concentrations ranging from 1 to $50 \mathrm{~mm}$, and L-NAME (Sigma) was used at a concentration of $0.1 \mathrm{~mm}$. CHX (Sigma) injections contained $500 \mathrm{ng}$ in $1 \mu \mathrm{l}$ of sterile saline (Harvey et al., 1994). The neurotrophins BDNF, NT-4/5, and NT-3 (Genentech) were contained in different carrier buffers. For BDNF, each $1 \mu \mathrm{l}$ injection contained 0.59 $\mu \mathrm{g}$ neurotrophin in a buffer of $10 \mathrm{~mm}$ acetate, $142 \mathrm{mM} \mathrm{NaCl}, \mathrm{pH} 5.5$. NT-4/5 was used at a concentration of $0.29 \mu \mathrm{g} / \mu \mathrm{l}$ in a carrier buffer of $10 \mathrm{~mm}$ acetate, $50 \mathrm{~mm} \mathrm{NaCl}, \mathrm{pH} 5.5$, and each $1 \mu \mathrm{l}$ injection of NT-3 contained $0.38 \mu \mathrm{g}$ of neurotrophin in a buffer of $0.05 \% \mathrm{II}_{3} \mathrm{PO}_{4}$ and $30 \%$ ethanol. The $\mathrm{EC}_{50}$ (half-maximal survival of responsive mouse neurons) for both BDNF and NT-4/5 is $5-10 \mathrm{pg} / \mathrm{ml}$, with saturation at $100 \mathrm{pg}$ / $\mathrm{ml}$ (Davies et al., 1993), and for NT-3 the $\mathrm{EC}_{50}$ is at $6 \mathrm{ng} / \mathrm{ml}$ (Rosenthal et al., 1990). NGF was dissolved in sterile saline and injected in concentrations ranging from 0.2 to $2 \mu \mathrm{g} / \mu \mathrm{l}$. After completion of our experiments the NGF was returned to the supplier (Dr. R. A. Rush) to confirm biological activity in E10 chick dorsal root ganglion assays. The NGF we used (Zettler et al., 1991) has an $\mathrm{EC}_{50}$ at $1 \mathrm{ng} / \mathrm{ml}$ (Rush, personal communication). LIF (in sterile saline) was used at a concentration of $0.63 \mu \mathrm{g} / \mu \mathrm{l}$. Sham eye injections were carried out in some 
lesioned rats using only sterile saline or the BDNF, NT- $4 / 5$, or NT-3 buffers.

Counts of DY-labeled RGCs in retinal whole-mounts. For fixation, rats were deeply anesthetized (Nembutal, i.p.) and perfused with $6 \%$ formaldehyde in $0.1 \mathrm{M}$ phosphate buffer ( $\mathrm{pH} 7.4$ ). Right eyes were removed and whole-mounts of the retinas were prepared. About $7 \%$ of retinas were not counted due to faint DY labeling, excessive autofluorescence, or if retinas showed signs of abnormal shrinkage (Harvey and Robertson, 1992). In the remaining retinas (290 in this study) the area containing the brightest labeling (usually about $10 \%$ or $2-3 \mathrm{~mm}^{2}$ of the total retinal area) was photographed using a $40 \times$ oil immersion objective (Harvey and Robertson, 1992; Cui and Harvey, 1994b; Harvey et al., 1994). Within the region of DY label, fields were randomly chosen for photography and counts of normal and frankly pyknotic DYlabeled RGCs were then made from the projected color images (Harvey and Robertson, 1992; Harvey et al., 1994). Fifteen fields $\left(0.714 \mathrm{~mm}^{2}\right)$ were photographed in each $6 \mathrm{hr}$ PL retina and 10 fields $\left(0.476 \mathrm{~mm}^{2}\right)$ in each $24 \mathrm{hr}$ PL retina. The data were obtained from 48 different litters. In no case was an individual litter used for only one experimental group; each litter contained rats injected with different substances, surviving either 6 or $24 \mathrm{hr}$ PL. In addition, there was almost always at least one lesion only or lesion plus sham eye-injected animal in each litter. When counting RGCs from each litter, the color slides were assigned a number and then randomly sorted so that the observer (Q.C.) did not know the origin of each retinal photomicrograph

About 2000-4500 RGCs were counted per retina. As in previous studies (Harvey et al., 1992; Harvey et al., 1994), most counts of normal and pyknotic DY-labeled RGCs were made within 1-2 mm of the optic nerve head, the majority in nasal retina. This is important because at P4/P5, RGC densities are generally uniform across the rat retina apart from a localized region of slightly lower density close to the superior margin (McCall et al., 1987). Thus density measurements were not significantly affected by interanimal variations in the location of RGC label in the retina. Assessment of cell density was subject to a small amount of interretinal variation due to differences in tissue shrinkage during fixation; however, pyknotic values were calculated as a proportion of total RGC number in each retina and were therefore not affected by such individual variations (Cui and Harvey, 1994b). For each experimental group the mean and standard deviation of the percentage of pyknotic RGCs and the density of normal DY-labeled RGCs per square millimeter were determined (Tables 1-3).

For statistical analysis of the $6 \mathrm{hr}$ and $24 \mathrm{hr}$ PL results, data were analyzed using one-factor analysis of variance using two-tailed Dunnett's $t$ tests (Dunnett, 1955). This rigorous procedure compares all treatment groups with a single control group; note that for numbers of treatments greater than 2, critical values in the Dunnett tables are larger than corresponding values using the Student's $t$ statistic. For the four data sets (rates of pyknosis and normal RGC densities, 6 and $24 \mathrm{hr}$ PL), Dunnett's test was used to analyze differences between experimental groups (including sham eye injection groups) and the respective lesiononly control group. In some cases, Bonferroni's test was used to analyze differences within particular treatment groups (e.g., to compare between different doses of NGF $24 \mathrm{hr}$ PL). We also used Dunnett's procedure to compare the rates of pyknosis in the $6 \mathrm{hr}$ lesion groups with the naturally occurring rate of RGC death in 4-5 d old rats (data from Cui and Harvey, 1994b). Values of $p>0.05$ indicated nonsignificant differences between groups.

\section{Results}

\section{$R G C$ death $6 \mathrm{hr}$ postlesion}

Examples of DY-labeled retinas $6 \mathrm{hr}$ PL are shown in Figure 1. Note that the number of pyknotic RGCs (arrows) is greatest in the lesion-only retina (Fig. $1 A$ ), is somewhat less in an eye injected with MK-801 (Fig. $1 B$ ) and is least in an NT-4/5-treated retina (Fig. $1 C$ ). The $6 \mathrm{hr}$ PL data are summarized in Table 1 and Figure $2 A$. In total, retinas from 114 rats were analyzed in this group. The mean rate of pyknosis in retinas from lesiononly rats was $1.88 \%$, which was significantly higher $(p<0.01)$ than the rate of pyknosis in nonlesioned rats of the same age (1.04\%; data from Cui and Harvey, 1994b). The proportion of dying DY-labeled RGCs in rats that received sham eye injections of $1 \mu \mathrm{l}$ of saline, BDNF buffer, or NT-3 buffer averaged $1.81 \%$,
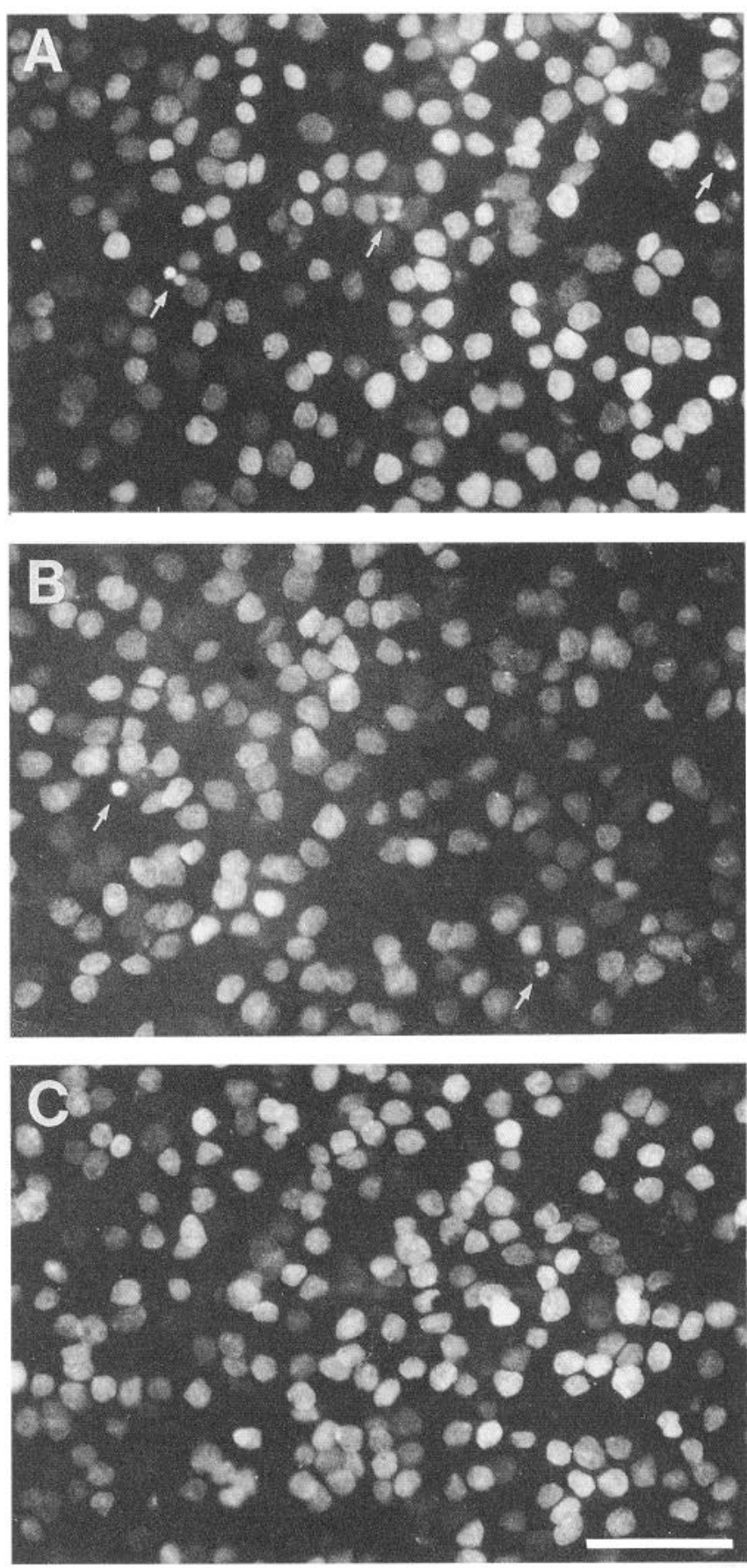

Figure 1. Representative photographs of DY-labeled retinas $6 \mathrm{hr}$ PL. $A$, Retina from lesion-only animal. $B$, Retina from MK-801-injected eye. $C$, Retina from NT-4/5-injected eye. Note the number of pyknotic profiles (arrows) is greatest in $A$ and least in $C$. Scale bar, $50 \mu \mathrm{m}$.

$2.19 \%$, and $2.06 \%$, respectively (mean for all sham eye-injections $=1.96 \%$; see Fig. $2 A$ ). The rates of pyknosis for each of these three groups were not significantly different from each other or from lesion-only animals.

Cycloheximide. Intraocular injection of $\mathrm{CHX}$ resulted in a mean pyknotic rate $6 \mathrm{hr}$ PL of $2.15 \%$, not significantly different from the rate in lesion-only controls (Table 1, Fig. $2 A$ ).

Glutamate antagonists. The rates of pyknosis in retinas of MK-801-, DNQX-, and CNQX-treated animals were $0.93 \%$, $0.94 \%$, and $1.0 \%$, respectively (Table 1 , Fig. $2 A$ ). All values 
Table 1. Experimental conditions and results $6 \mathrm{hr}$ after $\mathrm{SC}$ lesion

\begin{tabular}{|c|c|c|c|c|c|c|c|c|c|c|c|c|c|c|c|}
\hline & $\begin{array}{l}\text { Lesion } \\
\text { only }\end{array}$ & $\begin{array}{l}\text { BDNF } \\
\text { buffer }\end{array}$ & $\begin{array}{l}\text { NT-3 } \\
\text { buffer }\end{array}$ & Saline & $\mathrm{CHX}$ & MK801 & DNQX & $\begin{array}{l}\text { MK801 + } \\
\text { DNQX }\end{array}$ & CNQX & $\begin{array}{l}\text { L- } \\
\text { NAME }\end{array}$ & $\mathrm{NAC}$ & $\begin{array}{l}\text { NT- } \\
4 / 5\end{array}$ & BDNF & NT-3 & NGF \\
\hline $\begin{array}{c}\text { Number of } \\
\text { animals }\end{array}$ & 12 & 4 & 5 & 10 & 13 & 6 & 5 & 6 & 5 & 6 & 8 & 6 & 6 & 6 & 16 \\
\hline Dose $(\mu \mathrm{g} / \mu \mathrm{l})$ & & & & & 0.5 & $100 \mathrm{~nm}$ & $100 \mathrm{~nm}$ & $\begin{array}{l}\text { Each } \\
\qquad 100 \mathrm{~nm}\end{array}$ & $100 \mathrm{nM}$ & $0.1 \mathrm{~mm}$ & $1 \mathrm{~mm}$ & 0.29 & 0.58 & 0.38 & $0.2-1$ \\
\hline \multicolumn{16}{|l|}{ Pyknosis $(\%)$} \\
\hline Mcan & 1.88 & 2.19 & 2.06 & 1.81 & 2.15 & 0.93 & 0.94 & 1.24 & 1.0 & 0.85 & 0.97 & 0.25 & 0.55 & 0.75 & 1.86 \\
\hline SD & 0.26 & 0.55 & 1.29 & 0.51 & 0.72 & 0.47 & 0.33 & 0.26 & 0.21 & 0.24 & 0.23 & 0.18 & 0.15 & 0.37 & 0.59 \\
\hline \multicolumn{16}{|c|}{ Normal density (RGCs/mm²) } \\
\hline Mean & 5142 & 4884 & 4470 & 4816 & 5817 & 5677 & 5706 & 5946 & 6061 & 4964 & 5350 & 5820 & 5395 & 5508 & 5632 \\
\hline $\mathrm{SD}$ & 313 & 741 & 694 & 606 & 366 & 690 & 713 & 611 & 789 & 611 & 683 & 326 & 380 & 590 & 605 \\
\hline
\end{tabular}

Statistical analyses and significance levels are discussed in the text.

were significantly less than the proportion of dying RGCs in lesion-only rats $(p<0.01$ for MK-801 and DNQX; $p<0.05$ for $C N Q X)$. The average pyknotic rate in rats injected with a mixture of MK-801 and DNQX (Table 1, Fig. 2A) was also less than lesion-only rats but was not significantly different from the rates achieved using either glutamate receptor antagonist alone. Importantly, application of MK-801, DNQX, or CNQX reduccd pyknotic rates to a level that was not significantly different from naturally occurring RGC death (Fig. $2 A$ ).

$L-N A M E$ and NAC. Rates of pyknosis after intravitreal injection of L-NAME or NAC averaged $0.85 \%$ and $0.97 \%$, respectively (Table 1). These values were less than in lesion-only controls $(p<0.01)$ but, as with glutamate receptor antagonists, they were not significantly different from the rate of naturally occurring RGC death (Fig. 2A).

Neurotrophic factors. In retinas from NT-4/5-injected eyes, the mean rate of pyknosis $6 \mathrm{hr}$ PL was $0.25 \%$ (Table 1, Fig. $2 A)$. This rate was significantly less $(p<0.01)$ than that seen in lesion-only animals and was also less $(p<0.05)$ than the naturally occurring cell death rate of $1.04 \%$ (Cui and Harvey, 1994b). Intraocular injection of BDNF also reduced RGC death below the level seen in lesion-only rats $(p<0.01$; Table 1 , Fig. $2 \Lambda$ ); however, the rate of pyknosis was not significantly different from that seen in unlesioned animals.

RGC pyknosis in NT-3-treated retinas averaged $0.75 \%$ (Table 1, Fig. $2 A$ ), less than in lesion-only controls $(p<0.01)$ but not significantly different from the naturally occurring RGC death rate. Three different doses of NGF were applied intraocularly $(0.2,0.5$, or $1.0 \mu \mathrm{g}$ in $1 \mu \mathrm{l}$ of sterile saline). The proportions of DY-labeled RGCs that were pyknotic in these animals were $2.37 \%(n=5), 1.74 \%(n=5)$, and $1.55 \%(n=6)$, respectively. These data suggest that increasing the amount of NGF applied to the eye may have had a greater effect on preventing RGC death; however, the differences among NGF groups were not significant. Even the level of pyknosis in the rats with the highest dose of NGF was not significantly different from the lesion-only control group. Pooled together, the mean level of pyknosis in NGF-treated rats was $1.86 \%$ (Table 1, Fig. $2 A$ ).

Normal RGC densities. Compared with the pyknotic data, measurements of normal DY-labeled RGC density $6 \mathrm{hr}$ PL (Table 1) revealed few significant differences between treatment groups and lesion-only controls. This is in accord with a previous study (Harvey and Robertson, 1992) that showed that differences in $\mathrm{RGC}^{-}$density in $\mathrm{SC}$ lesioned versus nonlesioned rats only became apparent 8-12 hr PL. While, in many instances,
RGC densities appeared higher than in the lesion-only control group (Table 1), the only treatment group with a significantly higher $(p<0.05)$ density of normal RGCs was the group that received intravitreal injections of CNQX.

\section{$R G C$ death 24 hr postlesion}

Examples of DY-labeling in retinas $24 \mathrm{hr}$ PL are shown in Figure 3. Rates of pyknosis were high in retinas of lesion-only rats (Fig. 3A), and in DNQX (Fig. 3B), NT-3 (Fig. 3D), and NGF (Fig. $3 E$ ) injected eyes. Rates of pyknosis were lower and the densities of normal DY-labeled RGCs were higher in retinas from eyes injected with BDNF (Fig. 3C) or NT-4/5 (Fig. $3 F$ ). Summaries of most of the data are shown in Tables 2 and 3 (see also Figs. $2 B, 4$ ). A total of 158 animals was used in this part of the study. In lesion-only animals, the proportion of dying DYlabeled RGCs was $11.68 \%$. Sham eye injections using $1 \mu$ of BDNF buffer or sterile saline resulted in similar rates of pyknosis $(10.7 \%$ and $12.5 \%$, respectively). These rates were not significantly different from lesion-only controls.

Cycloheximide. Four animals received two intraocular injections of CHX, one immediately after the lesion and the second $12 \mathrm{hr}$ later. This treatment regime was the same as that described recently (Harvey et al., 1994) and was undertaken to check the efficacy of the CHX used in the $6 \mathrm{hr}$ PL group (Table 1, Fig. $2 A$ ). The rate of pyknosis $24 \mathrm{hr} \mathrm{PL}$ was $3.12 \%$ (Table 2, Fig. $2 B$ ), markedly similar to the $3.23 \%$ reported in an earlier article (Harvey et al., 1994) and significantly less $(p<0.01)$ than that seen in lesion-only animals. In accord with this reduction in RGC pyknosis, the mean density of normal DY-labeled RGCs was higher in CIIX-injected rats compared with lesion-only controls ( $p<0.01$; Table 2, Fig. 4).

Glutamate antagonists. The efficacy of MK-801 and DNQX in reducing $\mathrm{RGC}$ death $24 \mathrm{hr} \mathrm{PL}$ was tested in 14 rats. Either one or two intraocular injections were made in each animal. Neither of the glutamate antagonists was effective in reducing $\mathrm{RGC}$ death at this time and the two injection paradigm was no more effective than the single injection approach (Table 2, Fig. $2 B$ ). Pooling the data, the rate of pyknosis in rats treated with MK-801 was $11.64 \%$ and that in DNQX-injected animals was $11.7 \%$. Densities of normal DY-labeled RGCs in MK-801 and DNQX-treated retinas (one and two injection data pooled together) were higher than the average RGC density found in lesion-only rats (Table 2 ), perhaps reflecting the early neuronal protection rendered by these drugs in the first few hours after target removal; however, the differences were not significant. 

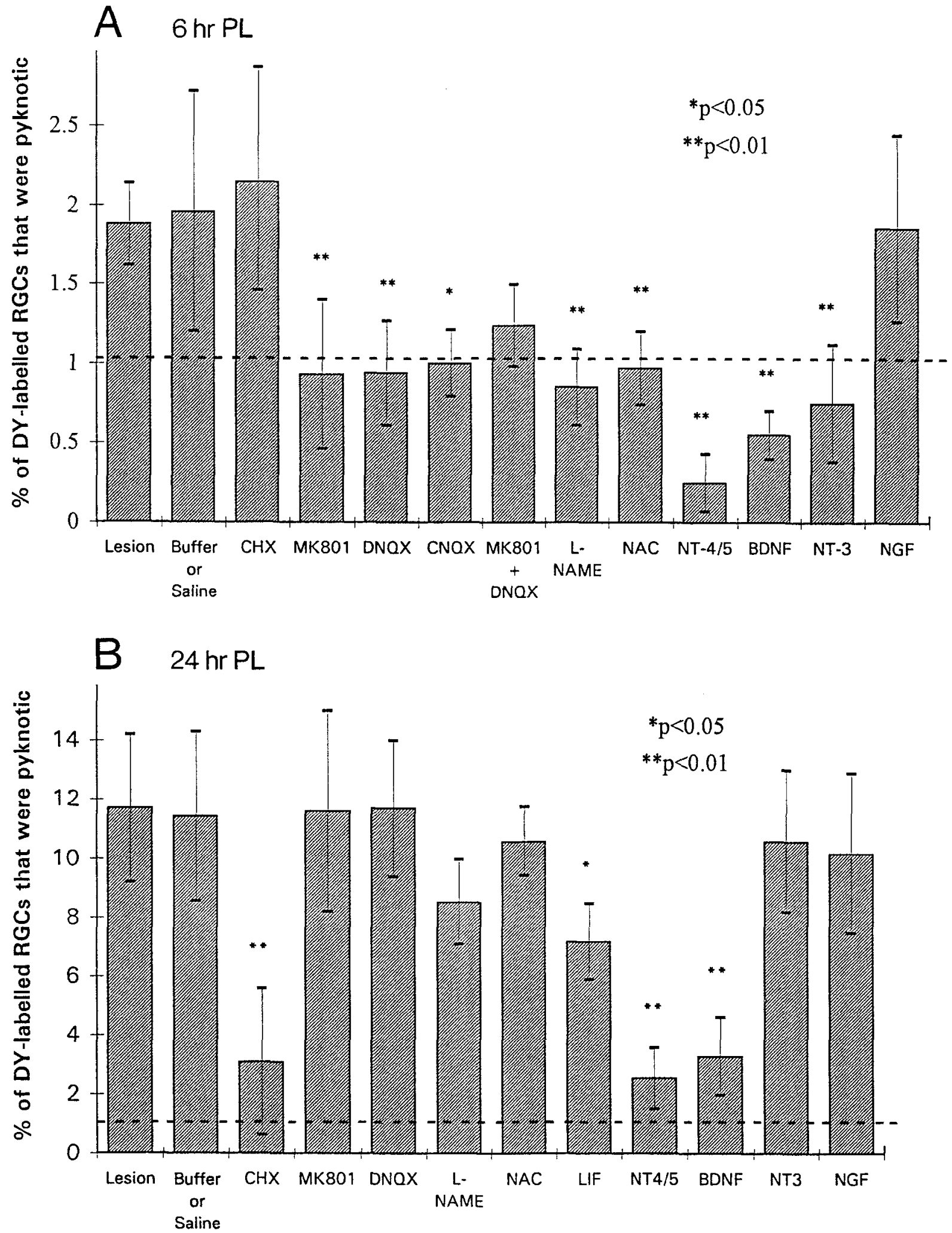

Experimental Groups

Figure 2. The mean percentage of DY-labeled RGCs that were pyknotic $6 \mathrm{hr}$ PL $(A)$ and $24 \mathrm{hr}$ PL (B). Standard deviations are also shown. The column labeled Buffer or Saline in $A$ and $B$ includes all animals that received sham eye injections (Tables 1,2 ). The dashed line in $A$ and $B$ shows the percentage of pyknotic RGCs in P4 rats in the absence of SC lesions (1.04\%), that is, the naturally occurring cell death rate (data from Cui and Harvey, 1994b). In $A$, the data for different doses of NGF have been pooled together. In $B$, the MK-801, DNQX, NT-4/5, BDNF, and NT-3 data are pooled from the single $(0 \mathrm{hr})$ and double $(0+12 \mathrm{hr})$ eye injection groups (Tables 2,3). The $24 \mathrm{hr}$ PL data for different doses of NGF have also been pooled together. Note that MK 801, DNQX, CNQX, L-NAME, NAC, and NT-3 prevented the lesion-induced increase in RGC death 6 hr after SC ablation but were ineffective 24 hr PL. CHX had no effect on pyknotic rates $6 \mathrm{hr}$ PL but did reduce RGC death measured $24 \mathrm{hr}$ PL. NT-4/5 and BDNF significantly reduced RGC pyknosis at both time points. 

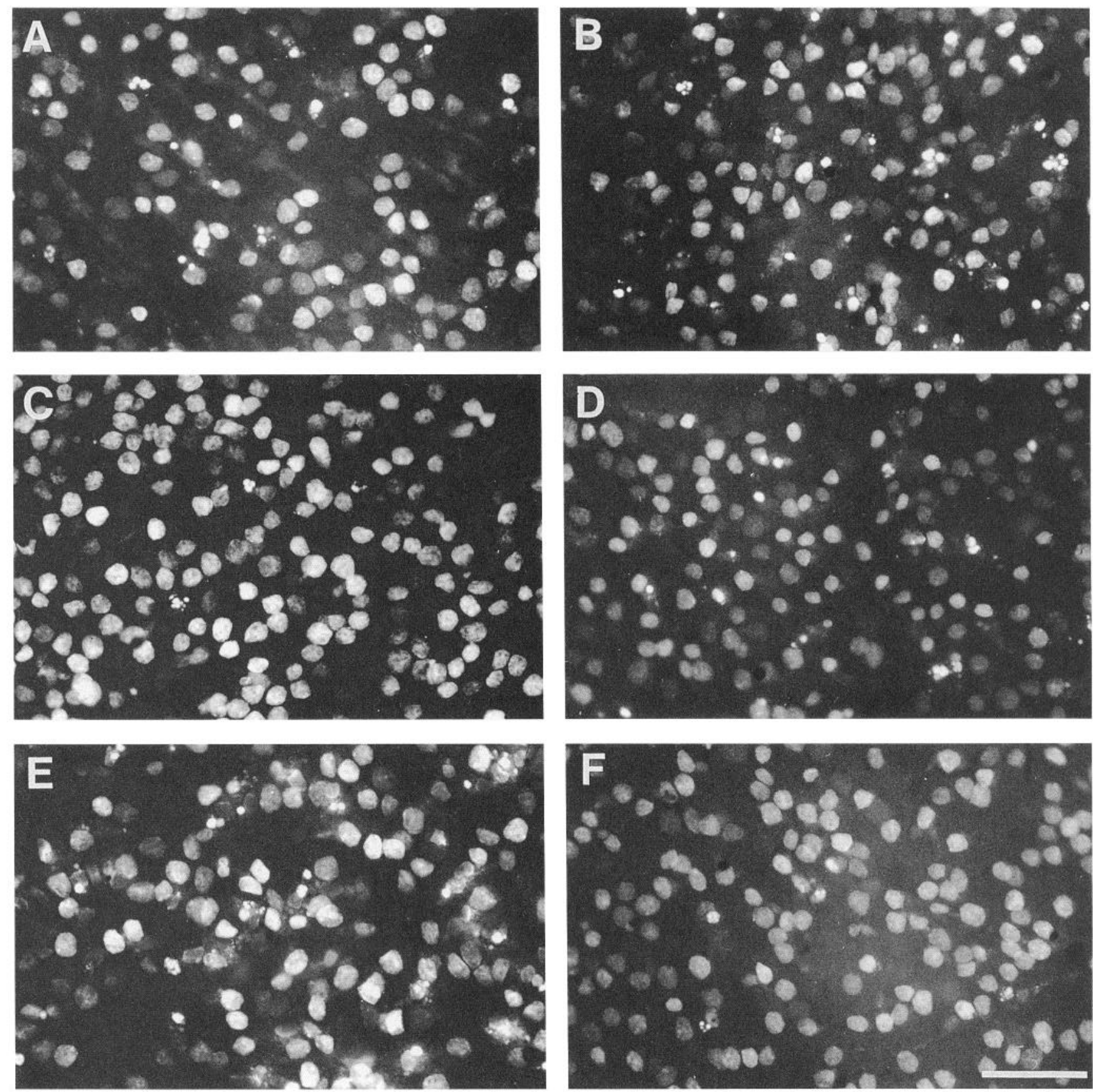

Figure 3. Representative photographs of DY-labeled retinas $24 \mathrm{hr}$ PL. $A$, Retina from lesion-only animal. $B$, Retina from DNQX-injected eye. $C$, Retina from BDNF-injected eye. $D$, Retina from NT-3-injected eye. $E$, Retina from NGF-injected eye. $F$, Retina from NT-4/5-injected eye. Note that the density of normal DY-labeled RGCs was greater and the number of pyknotic profiles was less in the BDNF $(C)$ and NT-4/5 $(F)$ treated eyes. Scale bar, $50 \mu \mathrm{m}$.

$L-N A M E$ and NAC. Unlike their effectiveness $6 \mathrm{hr}$ PL, intraocular injection of these factors at similar concentrations did not significantly reduce pyknosis or increase normal RGC density $24 \mathrm{hr}$ PL (Table 2, Fig. 2B). Note, however, that the mean rate of pyknosis after L-NAME treatment was less than in lesiononly rats (Fig. 2B) and only just failed to reach significance using Dunnett's procedure. In four additional animals, injection of a higher concentration $(50 \mathrm{~mm})$ of NAC also failed to be neuroprotective $24 \mathrm{hr}$ PL (mean rate of pyknosis $=12.14 \%$ ).

Neurotrophic factors: effects of BDNF, NT-3, NGF, and LIF. In all animals treated with these factors, one injection of the respective neurotrophic molecule was made immediately after the SC lesion. In some instances a second injection was made $12 \mathrm{hr}$ later (Table 2). After a single intravitreal injection of BDNF, the rate of dying DY-labeled RGCs was $3.0 \%$ compared with $3.71 \%$ after two injections; these two values were not significantly different from each other. Pooling the BDNF data gave a mean rate of pyknosis of $3.3 \%$, considerably lower than the rate in lesion-only animals ( $p<0.01$; Fig. $2 B$ ).

After one or two intraocular injections of NT-3, the proportion of dying DY-labeled RGCs averaged $11.71 \%$ and $9.57 \%$, respectively (Table 2), values that were not significantly different 
from each other. Combining the NT-3 data together gave a mean rate of pyknosis of $10.64 \%$, which was not significantly different from the lesion-only control group. The lack of effect of NT-3 at $24 \mathrm{hr}$ PL (Fig. 2B) contrasted with the more clearcut survivalpromoting influence of the neurotrophin $6 \mathrm{hr}$ after tectal ablation (Fig. 2A).

Three different doses of NGF were used $(0.5,1$, and $2.0 \mu \mathrm{g})$, all injected immediately after the SC lesion (Table 2). None of these regimes was effective in reducing RGC death $24 \mathrm{hr}$ PL. Pooling the NGF data, the mean pyknotic rate was $10.15 \%$ (Fig. $2 B$ ), which was not significantly different from lesion-only animals. Five animals lesioned at $\mathrm{P} 4$ received two intravitreal injections of LIF at 0 and $12 \mathrm{hr}$ PL. The proportion of dying RGCs in these animals averaged $7.19 \%$, which was less than in lesiononly rats $(p<0.05)$ but clearly not as dramatic a reduction as that seen after BDNF treatment.

The densities of normal DY-labeled RGCs $24 \mathrm{hr}$ PL were also assessed in these four treatment groups (Table 2). Densities in BDNF-treated retinas were higher than in lesion-only rats $(p<$ 0.01 ). The density of RGCs in those rats that received two BDNF eye injections was particularly high $\left(5208 / \mathrm{mm}^{2}\right)$. Normal RGC density in NT-3 and LIF-injected eyes were both higher ( $p<0.01$ for NT-3, $p<0.05$ for LIF) than lesion-only densities but similar to densities in rats that received sham eye injections of BDNF buffer (Table 2). The average density of normal DYlabeled RGCs in NGF-treated retinas was not significantly different from the lesion-only group. The greater density of normal RGCs in NT-3 versus NGF-injected eyes may reflect the early protective effect of NI-3 in the first few hours after target ablation.

Neurotrophic factors: effect of NT-4/5. In the initial experiments using NT-4/5, eye injections were made immediately after the SC lesion and in some cases a second injection was made $12 \mathrm{hr}$ later. This regime was thus the same as that used for other neurotrophic molecules (Table 2). The rates of RGC death in eyes receiving one or two NT-4/5 injections (Table 3) were not significantly different from each other, but were considerably less (pooled rate of pyknosis averaged $2.55 \%$; Fig. $2 B$ ) than rates found in retinas from lesion-only animals $(p<0.01)$. Correlated with this decrease in pyknosis, the density of normal DY-labeled RGCs in the nine NT-4/5-treated retinas was higher than in retinas from lesion-only rats ( $p<0.01 ;$ Fig. 4$)$.

We were intrigued by the fact that in the retinas of both BDNF and NT-4/5-injected rats examined 24 hr PL, pyknotic RGC rates were greatly reduced from the levels seen in lesion-only and sham eye-injected retinas; however, unlike the $6 \mathrm{hr} \mathrm{PL}$ group, rates were not reduced below the levels of naturally occurring cell death. The lowest rate in an individual $24 \mathrm{hr}$ PL animal injected with BDNF was $1.48 \%$ and a rate of $1.19 \%$ was seen in one rat twice injected with NT-4/5. In a previous study (Harvey and Robertson, 1992) it was shown that the beginning of the massive wave of RGC death following SC ablation began about $12 \mathrm{hr}$ PL and a pyknotic rate of about $3-4 \%$ was seen $14-$ $16 \mathrm{hr}$ after target loss. We hypothesized that the rate of about $3 \%$ seen $24 \mathrm{hr}$ after BDNF or NT-4/5 treatment might reflect a loss of efficacy of the trophic molecules in the eye about 8-10 $\mathrm{hr}$ after intravitreal injection; 14-16 hr later (24 hr PL) we were therefore seeing the early onset of a wave of RGC death, merely delayed by the application at $0 \mathrm{hr}$ PL of neurotrophic molecules. Thus in rats that received a second injection at $12 \mathrm{hr} \mathrm{PL}$, this second injection was too late to prevent many target-deprived RGCs from initiating a death program during the period (from 


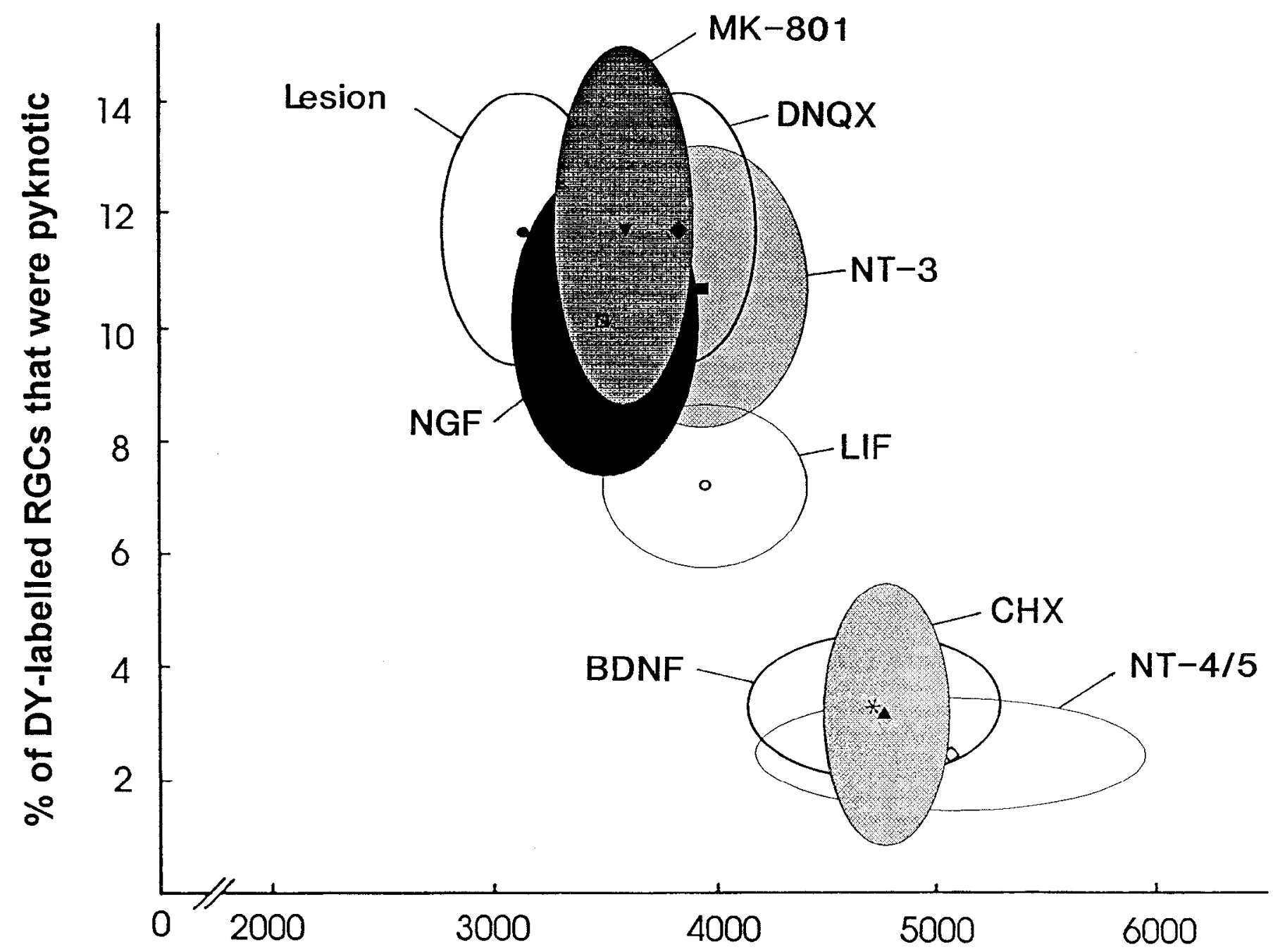

\section{Density of normal DY-labelled RGCs (per $\mathrm{mm}^{2}$ )}

Figure 4. Summary of 24 hr PL data showing the mean percentage of DY-labeled RGCs that were pyknotic versus the mean density (per mm ${ }^{2}$ ) of normal DY labeled RGCs for nine of the experimental groups (one and two injection data pooled for each group). For each group, the oval areas represent the standard deviations for rates of pyknosis and normal RGC density measurements. Note the consistent correlation between decreased rates of pyknosis and increased densities of normal RGCs.

8 to $12 \mathrm{hr}$ PL) during which trophic support was reduced or absent.

To test this hypothesis we carried out two further experiments. In one series of studies, rats received NT-4/5 injections immediately after SC ablation and a second injection was made either $5 \mathrm{~h}, 8 \mathrm{hr}$, or $20 \mathrm{hr}$ PL. Pyknotic rates in these animals averaged $1.81 \%, 2.97 \%$, and $4.59 \%$, respectively (Table 3). The rate of pyknosis in the group injected at 0 and $5 \mathrm{hr}$ was significantly different from the rate in the 0 and $20 \mathrm{hr}$ group $(p<0.05$, Bonferroni test), supporting the proposal that early application of the second injection sustained NT-4/5 levels in the $12 \mathrm{hr}$ following target removal and thus reduced the amount of RGC. death measured $24 \mathrm{hr}$ PL. Indeed, the lowest pyknotic rate in an individual animal from the 0 and $5 \mathrm{hr}$ injected group was $0.53 \%$, well below the level of naturally occurring RGC death in P4/P5 rats. Normal DY-labeled RGC density was also high in this treatment group (Table 3).

In a second experiment, rats received intraocular injections of
$\mathrm{NT}-4 / 5$ at 0 and $12 \mathrm{hr}$ after $\mathrm{SC}$ removal and the retinas were examined at different times after the target injury $(16,32,38$, or $48 \mathrm{hr} \mathrm{PL})$. The mean proportion of pyknotic RGCs in the four groups was $0.64 \%(n=4), 8.09 \%(n=6), 9.51 \%(n=$ $5)$, and $6.0 \%(n=3)$, respectively. With this injection regime, RGC pyknosis averaged $2.3 \%$ in rats perfused $24 \mathrm{hr}$ PL (Table $3)$. For comparison, without exogenous trophic support the rate of cell death $16 \mathrm{hr}$ PL was about $4 \%$ (Harvey and Robertson, 1992), it was $11.56 \%$ at $24 \mathrm{hr} \mathrm{PL}$ (present results), and $5.9 \%$ and $2.6 \%$ after $28 \mathrm{hr}$ and $50 \mathrm{hr}$, respectively (Harvey and Robertson, 1992). These comparisons confirm that intravitreal injection of NT-4/5 at the time of the lesion substantially reduced RGC death, but the neurotrophin was protective for only a limited period of time. After application of NT-4/5, the rate of RGC death was low until at least $16 \mathrm{hr}$ PL, was slightly increased at $24 \mathrm{hr}$ and peaked around 32-38 hr PL. In contrast, in the absence of exogenous support the peak of RGC death occurred at about 24 hr PL. 


\begin{tabular}{|c|c|c|c|c|c|c|c|c|c|}
\hline Number of animals & 4 & 5 & 6 & 5 & 11 & 5 & 5 & 11 & 11 \\
\hline Dose $(\mu \mathrm{g} / \mu \mathrm{l})$ & 0.29 & $0.29 \times 2$ & $0.29 \times 2$ & $0.29 \times 2$ & $0.29 \times 2$ & 0.29 & 0.29 & 0.29 & 0.29 \\
\hline $\begin{array}{l}\text { Time applied } \\
\text { (hours postlesion) }\end{array}$ & 0 & 0,12 & 0,5 & 0,8 & 0,20 & 12 & 16 & 20 & $\begin{array}{l}20 \text { (buffer } \\
\text { at } 0 \text { ) }\end{array}$ \\
\hline \multicolumn{10}{|l|}{ Pyknosis $(\%)$} \\
\hline Mean & 2.86 & 2.3 & 1.81 & 2.97 & 4.59 & 2.05 & 2.02 & 1.84 & 3.48 \\
\hline $\mathrm{SD}$ & 1.05 & 1.07 & 1.04 & 0.99 & 1.64 & 1.05 & 0.58 & 1.14 & 2.16 \\
\hline \multicolumn{10}{|c|}{ Normal density (RGCs/mm²) } \\
\hline Mean & 4780 & 4633 & 5925 & 4697 & 5543 & 4952 & 5479 & 4614 & 3925 \\
\hline $\mathrm{SD}$ & 356 & 491 & 944 & 681 & 759 & 272 & 515 & 787 & 486 \\
\hline
\end{tabular}

Statistical analyses and significance levels are discussed in the text.

The graph in Figure 4 summarizes much of the 24 hr PL data; each point shows the mean \% of pyknotic RGCs (y-axis) and the mean densily per mm ${ }^{2}$ of normal DY-labeled RGCs ( $x$-axis) for nine of the experimental groups (one and two injection data pooled for each group). For each group, the oval areas denote the standard deviations (pyknosis in the y-dimension, normal $\mathrm{RGC}$ density in the $\mathrm{x}$-dimension). In this figure, the NT-4/5 group includes all animals perfused $24 \mathrm{hr}$ PL $(n=20)$ that received an initial injection at time zero and a second injection 5,8 , or $12 \mathrm{hr}$ later (Table 3 ). It is important to note that decreased rates of pyknosis in CHX-, BDNF-, and NT-4/5-injected rats were consistently correlated with an increase in the number of normal DY-labeled RGCs per unit area. This correlation confirms that the three treatments suppressed RGC death for most of the $24 \mathrm{hr}$ period following $\mathrm{SC}$ removal. It also indicates that the low rates of pyknosis seen in these treatment groups were not due to a change in the time taken to remove and clear pyknotic nuclei (Harvey and Robertson, 1992).

Delayed application of NT-4/5. In in vitro studies it has been shown that, after trophic factor withdrawal, cells can still be rescued by delayed application of neurotrophic support (Edwards et al., 1991; Deckworth and Johnson, 1993). To test this in our in vivo model, the left $\mathrm{SC}$ of rats was injected with $\mathrm{DY}$ at $\mathrm{P} 2$, lesioned at $\mathrm{P} 4$ and $\mathrm{NT}-4 / 5$ was injected into the vitreous of the right eye 12,16 , or $20 \mathrm{hr}$ PL (Table 3 ). The rates of pyknosis in these three groups averaged $2.05 \%, 2.02 \%$, and $1.84 \%$, respectively. Clearly, application of an appropriate neurotrophic molecule as late as $20 \mathrm{lu}$ PL was still effective in significantly reducing RGC death when measured $24 \mathrm{hr}$ after target ablation.

The mean pyknotic rate in rats receiving one NT-4/5 injection $20 \mathrm{hr}$ PL was less ( $p<0.01$, Bonferroni test) than the rate seen in rats twice injected with NT-4/5, at 0 and $20 \mathrm{hr}$ PL (Table 3). The data seemed to indicate that the $20 \mathrm{hr}$ injection was less effective if the eye had been injected before. Was this due to previous exposure to NT-4/5 or was it due to less specific effects related to prior physical damage of the eyeball? In an attempt to answer this question, we carried out a further experiment in which rats received a sham eye injection of NT-4/5 buffer at time zero followed by an injection of NT-4/5 at $20 \mathrm{hr}$ PL (Table 3 ). There was an enormous range in this group; individual pyknotic values varied from $0.93 \%$ to $8.31 \%$ (mean $=3.48 \%$ ). Because of this variability, the mean rate of pyknosis for this group was not significantly different from the means for the $20 \mathrm{hr}$ PL delay group or the rats injected with NT-4/5 at 0 and $20 \mathrm{hr}$ PL

\section{Discussion}

The main aim of this study was to examine the influence of (1) neurotrophic factors, (2) glutamate receptor antagonists, and (3) inhibitors of NOS and free-radical formation on the viability of tectally projecting RGCs at various times after SC ablation in neonatal rats. We were particularly interested to determine the relative effectiveness of these different factors during the early and late phases of lesion-induced RGC death (i.e., $6 \mathrm{hr}$ and 24 hr PL).

\section{Two distinct mechanisms of $R G C$ death after neonatal target rerroval}

The observation that MK-801, DNQX, CNQX, L-NAME, and NAC all protected RGCs $6 \mathrm{hr}$ but not $24 \mathrm{hr}$ PL, whereas CHX was effective 24 hr but not 6 hr PL (cf. Harvey et al., 1994), strongly suggests that at least two distinct mechanisms are involved in RGC death following neonatal target ablation. The early phase of RGC death does not require protein synthesis but is dependent on glutamate receptor activation and appears to involve NOS and the production of free radicals. In contrast, the late phase is an active process requiring protein synthesis and, possibly, activation of some form of intrinsic suicide program (Martin et al., 1988; Oppenheim et al., 1990; Johnson and Deckworth, 1993). In accord with this, DNA fragmentation typical of apoptotic cell death has recently been described in neonatal (Rabacchi et al., 1994) and adult (Garcia-Valenzuela et al., 1994) RGCs following optic nerve lesion.

It is widely held that the cytotoxicity associated with excessive stimulation of glutamate receptors is due to $\mathrm{Ca}^{2+}$ influx and a subsequent increase in intracellular $\mathrm{Ca}^{2+}$ concentration (Choi, 1992). It has further been proposed that these increased levels of neuronal $\mathrm{Ca}^{2+}$ result in activation of $\mathrm{Ca}^{2+}$-dependent enzymes, in particular NOS, which in turn leads to an increase in the intracellular concentration of nitric oxide (NO) and the formation of damaging free radicals (Dawson et al., 1991; Lipton et al., 1993; Mayer and Noble, 1994; Dawson and Dawson, 1995). Our 6 hr PL data are clearly consistent with this type of death mechanism in neonatal RGCs. NMDA receptors have usually been implicated in neuronal excitotoxicity; however, there is accumulating evidence that $\mathrm{Ca}^{2+}$ influx through non-NMDA channels can also lead to death (Brorson et al., 1994). In the retina, MK-801 has been shown to protect RGCs and other neurons from NMDA and glutamate-induced toxicity (Abu El Asrar et al., 1992; Siliprandi et al., 1992; cf. Akaike et al., 1994), and from ischemic/hypoxic damage (Mosinger et al., 1991; Abu El 
Asrar et al., 1992); however, Mosinger et al. (1991) reported that antagonism of both NMDA and non-NMDA receptors was required for optimal protection against ischemia. Our results clearly demonstrate that blockade of either NMDA or nonNMDA receptors is equally as effective in preventing the increase in RGC death $6 \mathrm{hr}$ after target ablation. This is consistent with data showing that neonatal rat $\mathrm{RGCs}$ express a wide range of glutamate receptors that include NMDA and $\mathrm{Ca}^{2+}$-permeable non-NMDA channels (Müller et al., 1992; Rorig and Grantyn, 1993a,b; cf. Watanabe et al., 1994). Interestingly, the protective effects of NMDA and non-NMDA antagonists on RGCs $6 \mathrm{hr}$ PL were not additive, suggesting the involvement of a shared intracellular pathway in this degenerative process.

MK-801, DNQX, CNXQ, L-NAME, and NAC all reduced the rate of RGC pyknosis $6 \mathrm{hr} \mathrm{PL}$ but only to the level of naturally occurring cell death. In other words, these treatments specifically prevented the increase in death associated with SC injury. Clearly, naturally occurring RGC death and the early phase of lesion-induced RGC death are caused by different mechanisms. The lack of effect of MK-801, DNQX, or CNQX on ongoing naturally occurring RGC death is consistent with previous studies in normal (unlesioned) rats (Bunch and Fawcell, 1993; Cui and Harvey, 1994b), suggesting that during normal development NMDA and non-NMDA receptors do not play a significant role in regulating overall cell numbers in the postnatal rat retina. Note here that in other systems, use of MK-801 to block NMDA glutamate receptors can either decrease (O'Donoghue et al., 1993; Greensmith et al., 1994) or increase (Gould et al., 1994) naturally occurring cell death (cf. Yan et al., 1994). In the visual system, MK-801 treatment does, however, alter the pattern of RGC death in the developing eye, impairing the refinement of retinotectal topography (Bunch and Fawcett, 1993). It has recently been reported that the antioxidant NAC prevents apoptosis in neural cells (Mayer and Noble, 1994; Ferrari et al., 1995; cf. Greenlund et al., 1995). We found no evidence for the involvement of NO or free radicals in naturally occurring RGC death in vivo; however, it should be borne in mind that extracellular application of antioxidants need not necessarily be effective since the critical event in apoptosis may be the generation of free radicals within an individual neuron that act intracellularly and at short range (Greenlund et al., 1995).

\section{The morphology of dying RGCs}

In this and previous studies (Harvey and Robertson, 1992; Cui and Harvey, 1994b; Harvey et al., 1994), nuclei of RGCs projecting to the SC were identified using the retrograde fluorescent tracer DY. We then used nuclear condensation and fragmentation of labeled cells (features normally thought of as being typical of apoptosis) as the basis for our cell death counts. As reviewed previously (Harvey and Robertson, 1992), this type of degeneration in the retina has been described many times and in many different species, and is regarded as being the major morphological indicator of RGC death, both in normal development and after neonatal injury. The cffectiveness of glutamate receptor blockade in reducing pyknosis $6 \mathrm{hr} \mathrm{PL}$ suggests that, in the neonatal retina at least, excitotoxicity leads to a similar morphological end-point as protein synthesis-dependent apoptosis.

Classically, necrotic and apoptotic cell death can be distinguished both morphologically and pathophysiologically (Wyllie, 1987; Choi, 1992; Schwartzman and Cidlowski, 1993), although in his review Choi (1992) described excitoloxic changes as involving swelling followed by "degeneration of intracellular or- ganelles and nuclear pyknosis." Recent evidence provides support for the view that a clear distinction between necrosis and apoptosis cannot always be made. For example, in the cerebellum, pyknotic cells in the granule cell layer do not necessarily label for DNA fragmentation (Wood et al., 1993). It has also been shown that not all cells that undergo programmed cell death die via apoptosis and DNA cleavage is not always necessary (e.g., Schwartz et al., 1993). Excitotoxic injury can sometimes lead to so-called apoptotic changes-in that glutamateinduced death can be associated with DNA fragmentation and is prevented by transcription inhibitors or endonuclease inhibitors (Kure et al., 1991; Samples and Dubinsky, 1993; Mitchell et al., 1994). Others have commented that there is likely to be more than one trigger that activates a given intracellular cell death pathway (Vaux, 1993) and that it is sometimes difficult to make the "traditionally clear distinction between necrotic and apoptotic forms of cell death" (Rubin et al., 1994).

\section{The protective effects of $N T-4 / 5$ and $B D N F$}

NT-4/5 or BDNF treatment dramatically reduced the rate of RGC pyknosis measured 6 and $24 \mathrm{hr}$ PL. These neurotrophins thus protected neonatal RGCs during both the excitotoxic and protein synthesis-dependent phases of cell. Normal RGC density measured 24 hr PL was also much higher (Fig. 4), confirming that survival was enhanced thoughout most of this period. Consistent with these observations, both BDNF and NT-4/5 enhance RGC survival in vitro (Johnson et al., 1986; Thanos et al., 1989; Cohen et al., 1994) and BDNF has been shown to delay RGC death in adult rats after optic nerve section (Mey and Thanos, 1993; Mansour-Robaey et al., 1994) or after ischemia (Unoki and LaVail, 1994).

Neurotrophins can protect neurons after various types of acute traumatic insult. For example, BDNF enhances neuronal survival following glutamate-induced neurotoxicity (Lindholm et al., 1993; Shimohama et al., 1993; Cheng and Mattson, 1994), glucose deprivation (Cheng and Mattson, 1994), and ischemia (Unoki and LaVail, 1994). NT-4/5 also protects cells against energy deprivation and excitotoxicity (Cheng et al., 1994). The death of neurons resulting from excessive stimulation of glutamate receptors occurs even though, under other perhaps more physiological conditions, activation of NMDA-type receptors can induce the expression of neurotrophin mRNAs in the same neuronal populations (Zafra et al., 1991; Favaron et al., 1993; Hughes et al., 1993; cf. Hahn et al., 1988). The mechanisms by which exogenously applied neurotrophins protect neurons from glutamate neurotoxicity are not entirely understood, but there is evidence that they may act by stabilizing intracellular calcium levels, by limiting the formation of free radicals and/or by regulating the expression of the glutamate receptor proteins themselves (Choi, 1992; Mattson et al., 1993; Cheng and Mattson, 1994; Lindvall et al., 1994; Mattson and Scheff, 1994). In our in vivo system, the protective effects of NT-4/5 and BDNF $6 \mathrm{hr}$ PL may well have involved $\mathrm{Ca}^{2+}$ and/or free radical homeostasis, given that both L-NAME and NAC also prevented the early lesion-induced increase in $\mathrm{RGC}$ death.

There is now considerable evidence that one action of neurotrophins is to suppress endogenous suicide programs within neurons; loss of trophic support from a target results in the activation of a cascade of intracellular molecular events that leads to apoptotic neuronal death (Martin et al., 1988; Oppenheim et al., 1990; Scott and Davies, 1990; Edwards et al., 1991; Martin et al., 1992; Johnson and Deckworth, 1993). The efficacy of NT- 
4/5 and BDNF in reducing naturally occurring RGC death (cf. Cui and Harvey, 1994b) and in protecting RGCs $24 \mathrm{hr}$ after SC removal is consistent with this proposed action. While it is not known whether NT-4/5 is normally produced in developing central visual targets, there is evidence for the synthesis and presence of BDNF in the rodent SC (Hofer et al., 1990; Maisonpierre et al., 1990; Friedman et al., 1991). Note that injection of NT$4 / 5$ into neonatal eyes delayed but did not entirely eliminate this late, protein synthesis-dependent wave of RGC death. Data from two different series of experiments suggested that intravitreal injection of the neurotrophin delayed the onset of apoptosis in target-deprived RGCs for about 8-10 hr.

\section{Posttranslational effects of NT-4/5 in vivo}

NT-4/5 was still effective in protecting RGCs even when eye injections were delayed until 16-20 hr PL. We showed previously that delaying the injection of CHX until 12 hr PL significantly reduced its effectiveness in preventing $\mathrm{RGC}$ death after SC ablation (Harvey et al., 1994). As reviewed in that report, the CHX data were consistent with the idea of a "commitment point" for protein synthesis (Martin et al., 1992; Deckworth and Johnson, 1993), after which inhibition of macromolecular production cannot prevent the death of the cell. The fact that NT4/5 was still effective in promoting RGC survival when injected much later $(20 \mathrm{hr}$ PL) is consistent with tissue culture studies that showed that the time point at which deprived neurons could be rescued by readdition of NGF was much later than for $\mathrm{CHX}$ (Edwards et al., 1991; Deckworth and Johnson, 1993). As discussed by Deckworth and Johnson (1993), these in vitro observations show that trophic factors can reverse degenerative changes and prevent loss of cell viability a number of hours after critical levels of killer proteins (thanatins) have been reached. This may be achieved by inactivation of preexisting thanatins by a posttranslational mechanism or by a posttranslational modification of an alternate life-sustaining pathway within the cell (Edwards et al., 1991; Deckworth and Johnson, 1993).

\section{$R G C$ receptors for neurotrophins and cytokines}

There has been a plethora of recent reviews on the structure of neurotrophins and cytokines, the nature of their receptors, and what is currently known about the mechanisms of signal transduction (Korsching, 1993; Barbacid, 1994; Chao, 1994; Heumann, 1994; Ip and Yancopoulos, 1994; Kaplan and Stephens, 1994; Lindsay et al., 1994). All neurotrophins bind with similar affinity (but with different kinetics) to the low-affinity glycoprotein receptor p75 and high-affinity binding is mediated by the Trk family of tyrosine protein kinase receptors. The three known Trk receptors display distinct but overlapping specificities for the neurotrophins. Cytokines such as LIF and CNTF bind to a different type of receptor and utilize different signaling mechanisms, but may act synergistically with the neurotrophins (Ip and Yancopoulos, 1994). RGCs are sensitive to cytokines-we have shown that LIF reduces RGC death 24 hr PL and others have reported that CNTF has a protective effect on adult RGCs (Mey and Thanos, 1993; Cohen et al., 1994; Unoki and LaVail, 1994)_but the nature of the cytokine receptors expressed by RGCs is not yet known.

RGCs express both high- and low-affinity neurotrophin receptors. In development, RGCs and their axons transiently express high levels of the p75 receptor (Yan and Johnson, 1988; Carmignoto et al., 1991; Takahashi et al., 1993; cf. Allendoerfer et al., 1994). RGCs have also been reported to express TrkA
(Ernfors et al., 1992; Zanaletto et al., 1993; Rickman and Brecha, 1995), TrkB (Ernfors et al., 1992; Jelsma et al., 1993; Takahashi et al., 1993; Allendoerfer et al., 1994; Escandon et al., 1994; Rickman and Brecha, 1995), and TrkC (Ernfors et al., 1992; Allendoerfer et al., 1994; Escandon et al., 1994) receptors. Expression of TrkB is relatively high, particularly during development (Ernfors et al., 1992; Jelsma et al., 1993; Takahashi et al., 1993; Allendoerfer et al., 1994). $\Lambda$ s visual pathways mature, the full-length TrkB receptor is still found on RGCs, but the optic nerve and central target tissues contain mostly truncated TrkB transcripts (Jelsma et al., 1993; Allendoerfer et al., 1994). Taken together, it is highly likely that TrkB receptors mediated all of the protective effects of NT-4/5 and BDNF on neonatal RGCs described in the present study. It has been reported that NGF promotes RGC survival in vivo (Carmignoto et al., 1989; Siliprandi et al., 1993); however, in our hands NGF had no protective influence on the survival of tectally projecting RCCs, either 6 or $24 \mathrm{hr}$ after target loss. In accord with these data, NGF has not been found to significantly enhance the viability of fetal (Johnson et al., 1986) or adult (Thanos et al., 1989; Cohen et al., 1994) RGCs in vitro.

The NT-3 data were intriguing in that, after SC ablation, the neurotrophin enhanced RGC survival during the early excitotoxic phase but had no effect on the later, protein synthesisdependent phase of cell death. NT-3 also had no significant impact on the level of naturally occurring RGC death. This limited action of NT-3 may have been mediated by TrkC receptors, by one of the other Trk receptors, or perhaps by the low-affinity p75 receptor. The latter seems unlikely, first because $\mathrm{NGF}$, which also binds to $\mathrm{p} 75$, had no influence on RGC death, and second bccausc NT-3 still rescucd RGCs $6 \mathrm{hr}$ PL cven in the presence of antibodies (192-Ig) to the p75 receptor (Cui and Harvey, unpublished observations). The lack of effect of NGF also argues against the involvement of TrkA receptors, suggesting that the neuroprotective influence of NT-3 on RGC survival $6 \mathrm{hr}$ PL was most likely mediated by TrkC and/or perhaps by TrkB receptors. Certainly, the contrasting efficacy of NT-4/5 and NT-3 in preventing naturally occurring $\mathrm{RGC}$ death and in promoting neonatal RGC survival $24 \mathrm{hr}$ PL indicates that these neurotrophins were capable of activating different intracellular pathways within the neurons. Future molecular studies should help define the signaling mechanisms through which BDNF, NT-4/5, and NT-3 exert their different protective effects on neonatal RGCs, and may also show whether such mechanisms are involved in the maintenance of RGC viability in normal and axotomized adult retinas.

\section{References}

Abu El Asrar AM, Morse PH, Maimone D, Torczynski E, Reder AT (1992) MK-801 protects retinal neurons from hypoxia and the toxicity of glutamate and aspartate. Invest Ophthalmol Vis Sci 33:34633468 .

Akaike A, Tamura Y, Terada K, Nakata N (1994) Regulation by neuroprotective factors of NMDA receptor mediated nitric oxide synthesis in the brain and retina. Prog Brain Res 103:391-403.

Allendoerfer DM, Cabelli RJ, Escandan E, Kaplan DR, Nikolics K, Shatz CJ (1994) Regulation of neurotrophin receptors during matu ration of the mammalian visual system. J Neurosci 14:1795-1811.

Barbacid M (1994) The Trk family of neurotrophin receptors. J Neurobiol 25:1386-1403.

Brorson JR, Manzolillo PA, Miller RL (1994) $\mathrm{Ca}^{2+}$ entry via AMPA/ KA receptors and excitotoxicity in cultured cerebellar Purkinje cells. J Neurosci 14:187-197.

Bunch ST, Fawcett JW (1993) NMDA receptor blockade alters the 
topography of naturally occurring ganglion cell death in the rat retina. Dev Biol 160:434-442.

Carmignoto G, Maffei L, Candeo P, Canella R, Comelli C (1989) Effect of NGF on the survival of rat retinal ganglion cells following optic nerve section. J Neurosci 9:1263-1272.

Carmignoto G, Comelli MC, Candeo P, Cavicchioli L, Yan Q, Merighi A, Maffei L (1991) Expression of NGF receptor and NGF receptor mRNA in the development and adult rat retina. Exp Neurol 111:302311.

Carpenter P, Sefton AJ, Dreher B, Lim W-L (1986) Role of target tissue in regulating the development of retinal ganglion cells in the albino rat: effects of kainate lesions in the superior colliculus. J Comp Neurol 251:240-259.

Chao MV (1994) The p75 neurotrophin receptor. J Neurobiol 25:13731385.

Cheng B, Mattson MP (1994) NT-3 and BDNF protect CNS neurons against metabolic/excitotoxic insults. Brain Res 640:56-67.

Cheng B, Goodman Y, Begley JG, Mattson MP (1994) Neurotrophin$4 / 5$ protects hippocampal and cortical neurons against energy deprivation- and excitatory amino-acid-induced injury. Brain Res 650: 331-335.

Choi DW (1992) Excitotoxic cell death. J Neurobiol 23:1261-1276.

Cohen A, Bray GM, Aguayo AJ (1994) Neurotrophin-4/5 (NT-4/5) increases adult rat retinal ganglion cell survival and neurite outgrowth in vitro. J Neurobiol 25:953-959.

Cui Q, Harvey AR (1994a) BDNF but not NGF promotes the survival of retinal ganglion cells after loss of central target sites in neonatal Wistar rats. Proc Aust Neurosci Soc 5:125.

Cui Q, Harvey AR (1994b) NT-4/5 reduces naturally occurring retinal ganglion cell death in neonatal rats. Neuroreport 5:1882-1884.

Cui Q, Harvey AR (1995) At least two mechanisms are involved in retinal ganglion cell death following supcrior colliculus ablation in neonatal rats. Proc Aust Neurosci Soc 6:104.

Davies AM (1994) The role of neurotrophins in the developing nervous system. J Neurobiol 25:1334-1348.

Davies AM, Horton A, Burton LE, Schmelzer C, Vandlen R, Rosenthal A (1993) Neurotrophin-4/5 is a mammalian-specific survival factor for distinct populations of sensory neurons. J Neurosci 13:49614967.

Dawson TM, Dawson VL (1995) Nitric oxide: actions and pathological roles. Neuroscientist 1:7-18.

Dawson VL, Dawson TM, London ED, Bredt DS, Snyder SH (1991) Nitric oxide mediates glutamate neurotoxicity in primary cortical cultures. Proc Natl Acad Sci USA 88:6368-6371.

Deckwerth TL, Johnson EM Jr (1993) Temporal analysis of events associated with programmed cell death (apoplosis) of sympathetic neurons deprived of nerve growth factor. J Cell Biol 123:1207-1222.

Dreher B, Potts RA, Bennett MR (1983) Evidence that the early postnatal reduction in the number of rat retinal ganglion cells is due to a wave of ganglion cell death. Neurosci Lett 36:255-260.

Dunnett CW (1955) A multiple comparison procedure for comparing several treatments with a control. J Am Stat Assn 50:1096-1121.

Edwards SN, Buckmaster AE, Tolkovsky AM (1991) The death programme in cultured sympathetic neurons can be suppressed at the posttranslational level by nerve growth factor, cyclic AMP, and depolarization. J Neurochem 57:2140-2143.

Ernfors P, Merlio J-P, Persson II (1992) Cells expressing mRNA for neurotrophins and their receptors during embryonic rat development. Eur J Neurosci 4:1140-1158.

Escandon E, Soppet D, Rosenthal A, Mendoza-Ramirez JL, Szoenyi E, Burton LE, Henderson CE, Parada LF, Nikolics K (1994) Regulation of neurotrophin receptor expression during embryonic and postnatal development. J Neurosci 14:2054-2068.

Facci L, Leon A, Skaper SD (1990) Excitatory amino acid neurotoxicity in cultured retinal neurons: involvement of $N$-methyl-D-aspartate (NMDA) and non-NMDA receptors and effect of ganglioside GM1. J Neurosci Res 27:202-210.

Favaron M, Manev RM, Rimland JM, Candeo P, Beccaro M, Manev $\mathrm{H}$ (1993) NMDA-stimulated expression of BDNF mRNA in cultured cerebellar granule neurones. Neuroreport 4:1171-1174.

Ferrari G, Yan GYI, Greene LA (1995) N-acetylcysteine (b- and L-steroisomers) prevents apoptotic cell death of neuronal cells. J Neurosci 15:2857-2866.

Finlay BL, Pallas SL (1989) Control of cell number in the developing mammalian visual system. Prog Neurobiol 32:207-234.
Friedman WJ, Olson L, Persson H (1991) Cells that express brainderived neurotrophic factor mRNA in the developing postnatal rat brain. Eur J Neurosci 3:688-697.

Garcia-Valenzuela E, Gorczyca W, Dazynkiewicz Z, Sharma SC (1994) Apoptosis in adult retinal ganglion cells after axotomy. J Neurobiol $25431-438$.

Gould E, Cameron HA, McEwen BS (1994) Blockade of NMDA receptors increases cell death and birth in the developing rat dentate gyrus. J Comp Neurol 340:551-565.

Greenlund LJS, Deckworth TL, Johnson EM Jr (1995) Superoxide dismutase delays neuronal apoptosis: a role for reactive oxygen species in programmed neuronal death. Neuron 14:303-315.

Greensmith L, Mantis GZ, Vrbová G (1994) Blockade of $N$-methyl-Daspartate receptors by MK-801 (dizocilpine maleate) rescues motoneurones in developing rats. Dev Brain Res 81:162-170.

Hahn JS, Aizenman E, Lipton SA (1988) Central mammalian neurons normally resistant to glutamate toxicity are made sensitive by elevated extracellular $\mathrm{Ca}^{2+}$ : toxicity is blocked by the $N$-methyl-D-aspartate antagonist MK-801. Proc Natl Acad Sci USA 85:6556-6560.

Harvey AR, Robertson D (1992) The time-course and extent of retinal ganglion cell death following ablation of the superior colliculus in neonatal rats. J Comp Neurol 325:83-94.

Harvey AR, Cui Q, Robertson D (1994) The effect of cycloheximide and ganglioside GM1 on the viability of retinotectally projecting ganglion cells following ablation of the superior colliculus in neonatal rats. Eur J Neurosci 6:550-557.

Hefti $F$ (1994) Neurotrophic factor therapy for nervous system degenerative diseases. J Neurobiol 25:1418-1435.

Heunann R (1994) Neurotrophin signalling. Curr Opin Neurobiol 4:668-679.

Hofer M, Pagliusi SR, Hohn A, Leibrock J, Barde Y-A (1990) Regional distribution of brain-derived neurotrophic factor mRNA in the adult mouse brain. EMBO J 9:2459-2464.

Honorè T, Davies SN, Drejer J, Fletcher CJ, Jacobsen P, Lodge D, Nielsen F (1988) Quinoxalinediones: potent non-NMDA glutamate receptor antagonists. Science 241:701-703.

Horsburgh GM, Sefton AJ (1987) Cellular degeneration and synaptogenesis in the developing retina of the rat. J Comp Neurol 263:553566.

Hughes P, Beilhare E, Gluckndı P, Dragunow M (1993) Brain-derived neurotrophic factor is induced as an immediate early gene following $N$-methyl-D-aspartate receptor activation. Neuroscience 57:319-328.

Ip NY, Yancopoulos GD (1994) Neurotrophic factor receptors: just like other growth factor and cytokine receptors? Curr Opin Neurobiol $4: 400-405$

Jelsma TN, Friedman HH, Berkelaar M, Bray GM, Aguayo AJ (1993) Different forms of the neurotrophin receptor trkB mRNA predominate in rat retina and optic nerve. $J$ Neurobiol 24:1207-1214.

Johnson EM Jr, Deckwerth TL (1993) Molecular mechanisms of developmental neuronal death. Annu Rev Neurosci 16:31-46.

Johnson JE, Barde Y-A, Schwab M, Thoenen H (1986) Brain-derived neurotrophic factor supports the survival of cultured rat retinal ganglion cells. J Neurosci 6:3031-3038.

Kaplan DR, Stephens RM (1994) Neurotrophin signal transduction by the Trk receptor. J Neurobiol 11:1404-1417.

Korsching S (1993) The neurotrophic factor concept: a reexamination. J Neurosci 13:2739-2748.

Kure S, Tominaga T, Yoshimoto T, Tada K, Narisawa K (1991) Glutamate triggers internucleosomal DNA cleavage in neuronal cells. Biochem Biophys Res Comm 179:39-45.

Lindholm D, Dechant G, Heisenberg C-P, Thoenen H (1993) Brainderived neurotrophic factor is a survival factor for cultured rat cerebellar granule neurons and protects them against glutamate-induced neurotoxicity. Eur J Neurosci 5:1455-1464.

Lindsay RM, Wiegand SJ, Altar CA, DiStefano PS (1994) Neurotrophic factors: from molecule to man. Trends Neurosci 17:182-190.

Lindvall O, Kokaia Z, Bengzon J, Elmer E, Kokaia M (1994) Neurotrophins and brain insults. Trends Neurosci 17:490-496.

Lipton SA, Choi YB, Pan ZH, Lei SZ, Chen HSV, Sucker NJ, Loscalzo J, Singel DJ, Stamler JS (1993) A redox-based mechanism for the neuroprotective and neurodestructive effects of nitric oxide and related nitroso-compounds. Nature 364:626-632.

Maisonpierre PC, Belluscio L, Friedman B, Alderson RF, Wiegand SJ, Furth ME, Lindsay RM, Yancopoulos GD (1990) NT-3, BDNF and 
NGF in the developing rat nervous system: parallel as well as reciprocal patterns of expression. Neuron 5:501-509.

Mansour-Robaey S, Clarke DB, Wang Y-C, Bray GM, Aguayo AJ (1994) Effects of ocular injury and administration of brain-derived neurotrophic factor on survival and regrowth of axotomized retinal ganglion cells. Proc Natl Acad Sci USA 91:1632-1636.

Martin DP, Schmidt RE, DiStefano PS, Lowry OH, Carter JG, Johnson EM Jr (1988) Inhibitors of protein synthesis and RNA synthesis provent neuronal death caused by nerve growth factor deprivation. $\mathrm{J}$ Cell Biol 106:829-844.

Martin DP, Ito A, Horigome K, Lampe PA (1992) Biochemical characterization of programmed cell death in NGF-deprived sympathetic neurons. J Neurobiol 23:1205-1220.

Mattson MP, Scheff SW (1994) Endogenous neuroprotection factors and traumatic brain injury: mechanisms of action and implications for therapies. J Neurotrauma 11:3-33.

Mattson MP, Cheng B, Smith-Swintosky VL (1993) Mechanisms of neurotrophic factor protection against calcium- and free redical-mediated excitotoxic injury: implications for treating neurodegenerative disorders. Exp Neurol 124:89-95.

Maycr M, Noble M (1994) $N$-acetyl-L-cysteine is a pluripotent protector against cell death and enhances trophic factor-mediated cell survival in vitro. Proc Natl Acad Sci USA 91:7496-7500.

McCall MJ, Robinson SR, Dreher B (1987) Differential retinal growth appears to be the primary factor producing the ganglion cell density gradient in the rat. Neurosci Lett 79:78-84.

Meister A (1988) Glutathione metabolism and its selective modification. J Biol Chem 263:17205-17208.

Mey J, Thanos S (1993) Intravitreal injections of neurotrophic factors support the survival of axotomized retinal ganglion cells in adult rats in vivo. Brain Res 602:304-317.

Mitchell IJ, Lawson S, Moser B, Laidlaw SM, Cooper AJ, Walkinshaw G, Waters CM (1994) Glutamate-induced apoptosis results in a loss of striatal neurons in the Parkinsonian rat. Neuroscience 63:1-5.

Moncada S, Palmcr RMJ, Higgs EA (1991) Nitric oxide: physiology, pathophysiology, and pharmacology. Pharmacol Rev 43:109-142.

Mosinger JL, Price MT, Bai HY, Xiao H, Wozniak DF, Olney JW (1991) Blockade of both NMDA and non-NMDA receptor is required for optimal protection against ischemic neuronal degeneration in the in vivo adult mammalian retina. Exp Neurol 113:10-17.

Müller F, Greferath U, Wässle H, Wisden W, Seeburg P (1992) Glutamate receptor expression in the rat retina. Neurosci Lett 138:179182.

O'Donoghue DL, Poff CRD, Block JJ (1993) Chronic neonatal $N$-methyl-D-aspartate receptor antagonism with MK-801 increases the number of corticospinal cells retained into adulthood in the rat. Neurosci Lett 158:143-146.

Oppenheim RW (1991) Cell death during development of the nervous system. Annu Rev Neurosci 14:453-501.

Oppenheim RW, Prevette D, Tytell M, Homma S (1990) Naturally occurring and induced neuronal death in the chick embryo in vivo required protein and RNA synthesis: evidence for the role of cell death genes. Devel Biol 138:104-113.

Perry VH, Cowey A (1979) The effects of unilateral cortical and tectal lesions on retinal ganglion cells in rats. Exp Brain Res 35:85-95.

Perry VH, Henderson Z, Linden $R$ (1983) Postnatal changes in retinal ganglion cell and optic axon populations in the pigmented rat. I Comp Neurol 219:356-368.

Rabacchi SA, Bonfant L, Liu X-H, Maffei L (1994) Apoptotic cell death induced by optic nerve lesion in the neonatal rat. $J$ Neurosci 14:5292-5301.

Rickman DW, Brecha NC (1995) Expression of the proto-oncogene, trk, receptors in the developing rat retina. Vis Neurosci 12:215-222.

Rorig B, Grantyn R (1993a) Rat retinal ganglion cells express $\mathrm{Ca}^{2+}$. permeable non-NMDA glutamate receptors during the period of histogenetic cell death. Neurosci Lett 153:32-36.

Rorig B, Grantyn R (1993b) Glutamatergic and GABAergic synaptic currents in ganglion cells from isolated retinae of pigmented rats during postnatal development. Dev Brain Res 74:98-110.

Rosenthal A, Goeddel DV, Nguyen T, Lewis M, Shih A, Laramee GR, Nikolics K, Winslow JW (1990) Primary structure and biological activity of a novel human neurotrophic factor. Neuron 4:767-773.
Rubin LL, Gatchalian CL Rinion G, Brooks SF (1994) The molecular mechanisms of neuronal apoptosis. Curr Opin Neurobiol 4:696-702.

Samples SD, Dubinsky JM (1993) Aurintricarboxylic acid protects hippocampal neurons from glutamate excitotoxicity in vitro. J Neurochem 61:382-385.

Schwartz LM, Smith SW, Jones MEE, Osborne BA (1993) Do all programmed cell deaths occur via apoptosis? Proc Natl Acad Sci USA 90:980-984.

Schwartzman RA, Cidlowski JA (1993) Apoptosis: the biochemistry and molecular biology of programmed cell death. Endocr Rev 14: $133-151$.

Scott SA, Davies AM (1990) Inhibition of protein synthesis prevents cell death in sensory and parasympathetic neurons deprived of neurotrophic factor in vitro. J Neurobiol 21:630-638.

Shimohama S, Tamura Y, Akaike A, Tsukahara T, Ohara O, Watanabe S, Kimura J (1993) Brain-derived neurotrophic factor pretreatment exerts a partially protective effect against glutamate-induced neurotoxicity in cultured rat cortical neurons. Neurosci Lett 164:55-58.

Sievers J, Hausmann B, Unsicker K, Berry M (1987) Fibroblast growth factors promote the survival of adult rat retinal ganglion cells after transection of the optic nerve. Neurosci Lett 76:157-162.

Siliprandi R, Canella R, Carmignoto G, Schiavo N, Zanella A, Zanoni $\mathrm{R}$, Vantini $\mathrm{G}$ (1992) $\mathrm{N}$-methyl-D-aspartate-induced neurotoxicity in the adult rat retina. Vis Neurosci 8:567-573.

Siliprandi R, Canella R, Carmignoto G (1993) Nerve growth factor promotes functional recovery of retinal ganglion cells after ischemia. Invest Ophthalmol Vis Sci 34:3232-3245.

Snider WD, Elliott JL, Yan Q (1992) Axotomy-induced neuronal death during development. J Neurobiol 23:1231-1246.

Sohal GS (1992) The role of target size in neuronal survival. J Neurobiol 23:1124-1130.

Takahashi JB, Hoshimaru M, Kikuchi H, Hatanaka M (1993) Developmental expression of trkB and low-affinity NGF receptor in the rat retina. Neurosci Lett 151:174-177.

Thanos S, Bähr M, Barde Y-A, Vanselow L, (1989) Survival and axonal elongation of adult rat retinal ganglion cells. In vitro effects of lesioned sciatic nerve and brain derived neurotrophic factor. Eur J Neurosci $1: 1926$.

Unoki K, LaVail MM (1994) Protection of the rat retina from ischemic injury by brain-derived neurotrophic factor, ciliary neurotrophic factor, and basic fibroblast growth factor. Invest Ophthalmol Vis Sci 35: 907-915.

Vaux DL (1993) Toward an understanding of the molecular mechanisms of physiological cell death. Proc Natl Acad Sci USA 90:786789 .

Watanabe M, Mishina M, Inoue Y (1994) Differential distribution of the NMDA receptor channel subunit mRNAs in the mouse retina. Brain Res 634:328-332.

Wong EHF, Kemp JA, Priestley T, Knight AR, Woodruff GN (1986) The anticonvulsant MK-801 is a potent $N$-methyl-D-aspartate antagonist. Proc Natl Acad Sci USA 83:7104.

Wood KA, Dipasquale R, Youle R.T (1993) In situ labelling of granule cells for apoptosis-associated DNA fragmentation reveals different mechanisms of cell loss in developing cerebellum. Neuron 11:621632.

Wyllie AH (1987) Apoptosis: cell death in tissue regulation. J Path 153:313-316.

Yan G-M, Ni B, Weller M, Wood KA, Paul S.M (1994) Depolarization or glutamate receptor activation blocks apoptotic cell death of cultured cerebellar granule neurons. Brain Res 656:43-51.

Yan Q, Johnson EM Jr (1988) An immunohistochemical study of the nerve growth factor receptor in developing rats. J Neurosci 8:34813498.

Zafra F, Castren E, Thoenen H, Lindholm D (1991) Interplay between glutamate and $\gamma$-aminobutyric acid transmitter systems in the physiological regulation of brain-derived neurotrophic factor and nerve growth factor synthesis in hippocampal neurons. Proc Natl Acad Sci USA 83:9444-9448.

7analetto A, Comelli MC, Toso RD, Carmignoto G (1993) Developing retinal ganglion cells express the functional NGF receptor pl 40trkA. Dev Biol 159:105-113.

Zettler C, Head RJ, Rush RA (1991) Chronic nerve growth factor treatment of normotensive rats. Brain Res 538:251-262. 